This item was submitted to Loughborough's Research Repository by the author.

Items in Figshare are protected by copyright, with all rights reserved, unless otherwise indicated.

\title{
The unfulfilled promise of management education (ME): The role, value and purposes of ME
}

PLEASE CITE THE PUBLISHED VERSION

http://dx.doi.org/10.1108/02621711311328255

PUBLISHER

(C) Emerald

VERSION

AM (Accepted Manuscript)

\section{PUBLISHER STATEMENT}

This work is made available according to the conditions of the Creative Commons Attribution-NonCommercialNoDerivatives 4.0 International (CC BY-NC-ND 4.0) licence. Full details of this licence are available at: https://creativecommons.org/licenses/by-nc-nd/4.0/

\section{LICENCE}

CC BY-NC-ND 4.0

\section{REPOSITORY RECORD}

Thomas, Howard, Lynne Thomas, and Alexander D. Wilson. 2019. "The Unfulfilled Promise of Management Education (ME): The Role, Value and Purposes of ME”. figshare. https://hdl.handle.net/2134/18544. 


\section{The Unfulfilled Promise of Management Education (ME): The Role, Value and Purposes of ME \\ Howard Thomas (Singapore Management University) \\ Lynne Thomas (Visual Coaching and Counselling) \\ Alexander Wilson (Singapore Management University and Loughborough University, U.K.)}

\section{Abstract}

\section{Purpose}

The paper reviews the evolution of management education primarily over the last 50 years and seeks to identify the challenges and lessons learned in management education and to assess the potential for change. To gain insight into these issues the authors draw on the perspectives of around 40 key individuals from academia, professional bodies, media, business and students.

\section{Design/methodology/approach}

The content of the paper is based upon a qualitative analysis of around 40 2-3 hour interviews of key global players in the management education field.

\section{Findings}

The key stakeholders in management education are identified as students, business and employers respectively. But in terms of relative stakeholder influence faculty, business and students are the top 3 influencers. Faculty represent the supply-side whereas business and students represent the demand side of management education. There is evidence that higher tuition fees may increase the power of students and business relative to faculty.

The individuals who have had the greatest influence on management education are academics such as Mintzberg and Drucker rather than business school deans or administrators. Institutions such as INSEAD, IMD and Harvard have had the greatest influence. The main issues and challenges identified in Management Education include information technology, globalisation, the role of faculty, competition and business model performance. Few game changing innovations in curricula have occurred in management education raising the question of how change will occur in the future.

\section{Originality / value}

There are few in-depth, open-ended interview studies of key participants in the field of management education. It adds insights to a range of more reflective literature studies from writers such as Khurana, Mintzberg and Pfeffer. 
Key words

Stakeholders, Opinion Leaders, Leading Business Schools, Globalisation, Information Technology, Faculty, Competition, Business Models, Management Education. 


\section{The Unfulfilled Promise of Management Education (ME): The Role, Value and Purposes of ME1}

By Howard Thomas (Singapore Management University)

Lynne Thomas (Visual Coaching and Counselling)

Alexander Wilson (Singapore Management University and Loughborough University, U.K.)

\section{Introduction}

Despite the continued success and growth of management education many writers, including particularly Rakesh Khurana (2007) in his important review of U.S. management education, have pointed to the 'unfulfilled promise' of management education. The extensive critiques of management education also attest to the contested nature of debates about the role, legitimacy, and academic and social status of business schools. They argue that business schools currently face an image and identity crisis.

In the evolution of business schools there have been a number of key milestones en route to the present somewhat confused set of affairs. In the initial "trade-school" era, in the late $19^{\text {th }}$ to the early $20^{\text {th }}$ century, the original purpose of management education centred on the idea of a liberal and moral education for business people. The aim was to enhance the status of the professional manager in public and private life. Pioneer schools, such as the Wharton School (influenced by the founder Joseph Wharton and Taylor's scientific management principles) and Harvard Business School, thus became the catalysts of the future growth of business schools. The founding of AACSB (the American Association for Collegiate Schools of Business) in 1916 closely followed the growth of the new business schools. However, these schools did little, or no, research and were seen by Herb Simon as 'wastelands of vocationalism'.

The Gordon/Howell (Ford/Carnegie Foundation sponsored) reports (1959) in the U.S. in the late 1950 's, were, therefore, charged to examine the claim that business schools lacked research output, academic credibility and legitimacy. These reports proposed an alternative business school model that emphasised strong social science perspectives and academic rigour. Its educational philosophy - logical positivism - embodied discipline-led scholarship with a clear focus on analytical models and scientific rigour. Business schools generally adopted this model. Indeed this U.S. model together with a redesigned general management MBA degree became the dominant design for business schools.

By the late 1970's and early 1980's concerns began to emerge from practitioners and academics about the overly scientific focus of business schools and the irrelevant nature of management research. Notable academic critics included Professors Hayes, Abernathy, Levitt and Livingston at Harvard Business School. As a consequence, the field of management education saw the emergence of readable management books from authors such as Jim Collins (2001), Gary Hamel and C.K. Prahalad (1994), and Michael Porter (1980). These books told, through the vehicle of cases and well-constructed stories, how managers and leaders addressed and handled strategic issues such as

\footnotetext{
${ }^{1}$ This is an updated version of the paper published in Global Focus, 6(2), 2012, pp1-19. It summarises a few of the observations made in the EFMD sponsored book Promises Fulfilled and Unfulfilled in Management Education H. Thomas, L. Thomas and A. Wilson: Emerald, 2013.
} 
competition, diversification and organisational change. They helped to bridge the gap between academic research and managerial relevance and had strong appeal for the growing generation of managers and 'fast-track' leaders.

During this same time period European management schools, such as HEC, IESE, IMD, INSEAD and LBS, established their growing influence in management education (see Howard Thomas, '2012). They stressed elements which were more reflective of European traditions including action-learning, practice engaged research, customised executive education and, most importantly, a focus on international linkages, activities and research. It is now clear that there is already a European identity and style in management education and also a rapidly evolving Asian identity and style.

Nevertheless criticism of business schools and management education has continued in an unabated fashion. The conventional judgement is that the business school model is definitely in transition and business schools are at a 'turning point' in their evolution.

The concerns of some of the most eloquent critics must be recognised in the transformation process in this transitionary period.

- Jeff Pfeffer and Christina Fong (2002) at Stanford have suggested that business schools are too market driven and that management research has fallen short of good scientific traditions.

- Henry Mintzberg (2004) has argued that management is an art, not a science, and that the emphasis on analytical methodology and science in business schools is misplaced. He maintains that the traditional MBA curriculum is too narrow and specialised and ignores the development of leadership and management skills.

- The late Sumantra Ghoshal (2005) pointed out the moral decline of business and argued that business schools had been guilty of propagating and teaching amoral theories that destroyed sound management practices.

- Recently, Edwin Locke and J.C. Spender (2011) amplified Ghoshal's arguments and showed how the business school focus on numbers, mathematical modelling and theories, and specifically those based on financial economics, can lead to rational choices which ignore important issues of culture, managerial behaviour and ethics. They conclude that market capitalism has evolved into 'casino capitalism', largely absent of a moral and ethical compass, in which the lack of financial morality and ethical leadership partially fuelled the global economic crisis of 2008.

Indeed, business schools have been blamed not only for their influence on the global financial crisis but also for ethical business failures such as Enron and WorldCom in the U.S. and Parmalat in Europe. Rakesh Khurana has observed that a manager's role has shifted from 'higher aims' as professional stewards of a firm's resources to that of 'hired hands' operating only on the basis of contractual relationships. A key consequence of this demoralisation and de-professionalisation of managers is that the self-interest of relevant parties has overcome a proper ethical and moral compass and that the principle of trust that was central to the operation of market capitalism has been abandoned. Clearly, the ethical tradition in business life is in danger of erosion by the institutionalisation of management education and business schools in their current form. Others, including Chris Grey (2005) of Warwick Business School, have argued that business schools have 
become 'finishing schools' for elites to prepare for positions in finance and consulting without confronting them to examine the ethical and moral challenges of leadership and reflect on their broader roles in society.

It is, therefore, urgent for management educators to engage in a period of sustained reflection about the purpose of management education. Important questions include the following:

- What is business for?

- What are business schools for?

- Who are the key stakeholders in management education?

- Should the curriculum of management education emphasise breadth and a holistic perspective encompassing disciplines, theories, models, cultures, ethics, social science, history, philosophy etc. and embracing traditions of both analysis and synthesis?

There is clearly an emerging and important school of thought promoted by agencies such as EABIS, GLRI, PRME, UN Global Compact and the 50/20 WBSCB group, which advocates that the business school is a human institution embracing humanistic and societal values and that management is a creative art and not a deterministic science. Therefore it is important to view management education from a wide range of stakeholder perspectives, e.g. society, business, government, students, employers etc., even though currently curricula in business schools pay 'lip service' to these topics showing more evidence of rhetoric rather than reality in their actions. In short, their position is that the sole purpose of firms is not to maximise shareholder wealth and that firms must deploy their power in a socially responsible manner in balancing the competing interests of different stakeholders. We, therefore, believe it is imperative to examine the stakeholder perspective in management education as an alternative model in a systematic fashion.

This paper consequently focusses on the relative influence of stakeholders, individuals and organisations: The issues they focus on, the lessons not learned and the potential for change. To gain insight into these issues we draw on the perspectives of interview participants from a range of stakeholder groups in management education. The debate and criticism surrounding management education energises a number of stakeholders and changes their relative interests and influence. Understanding the relations and interactions between the various actors in management education is fundamental to our analysis of the roles, value and purpose of management education. This research is based on a series of in-depth interviews conducted across a set of stakeholders to develop a more comprehensive and informed view. 39interviews lasting between 2 and 3 hours each were conducted taking in the informed views of stakeholders from academia, professional bodies, media, business and students. Interviews followed a semi-structured design to guide key thematic areas and to allow respondents the flexibility to expand on issues they found relevant and important to the discussion. Interviewees were asked to focus on the time period from EFMD's formation in 1971 to present and also to consider the likely future scenarios for management education.

\section{Stakeholders in management education}

Who are the most important stakeholders in management education? 
At the centre of the criticisms and challenges facing management education is an apparent disconnect between the role of business schools and the expectations and experiences of stakeholders. Respondents were asked who they consider key stakeholders to be, which stakeholder has the greatest influence as well as to identify the role of their own stakeholder group. These are questions that are implicitly raised by critics and commentators on management education. For example, the criticism that management research is irrelevant contains a substantial disconnect between stakeholders - for whom is management research relevant and why? Despite this, rarely is the management education community asked directly to discuss the position and role of its own stakeholders. There is therefore a clear and current need to better understand the roles and needs of stakeholders in management education.

The first question asked 'Who do you consider to be the key stakeholders in management education?' Where possible, respondents were also asked to rank order key stakeholders by their relative importance within management education.

Table 1: Key stakeholders in management education

\begin{tabular}{|l|r|r|r|r|r|r|r|r|}
\cline { 2 - 9 } \multicolumn{1}{l|}{} & Students & Organizations/Business & Employers & Faculty & University & Others & Government & Society \\
\hline 1st & $46 \%$ & $17 \%$ & $11 \%$ & $6 \%$ & $3 \%$ & $0 \%$ & $6 \%$ & $11 \%$ \\
\hline 2nd & $26 \%$ & $17 \%$ & $14 \%$ & $9 \%$ & $6 \%$ & $6 \%$ & $9 \%$ & $0 \%$ \\
\hline 3rd & $6 \%$ & $17 \%$ & $6 \%$ & $11 \%$ & $11 \%$ & $14 \%$ & $3 \%$ & $3 \%$ \\
\hline $\begin{array}{l}\text { 1st and } \\
\text { 2nd }\end{array}$ & $72 \%$ & $34 \%$ & $25 \%$ & $14 \%$ & $9 \%$ & $6 \%$ & $14 \%$ & $11 \%$ \\
\hline Top 3 & $78 \%$ & $51 \%$ & $31 \%$ & $26 \%$ & $20 \%$ & $20 \%$ & $17 \%$ & $14 \%$ \\
\hline
\end{tabular}

Table 1 shows that students are identified as the most important stakeholders in management education with nearly half the respondents placing them first and over three quarters of respondents placing them in the top 3 most important stakeholders. However, this is not as clear-cut as it first appears. This question prompted much critical reflection by respondents and an analysis of the interview data reveals underlying issues in identifying key stakeholders. These can be divided into two categories of response: The first is a pragmatic assessment that contrasts who should be a key stakeholder with which groups are best served under current arrangements. The second draws a distinction between the types of student involvement in management education and specifically focuses on the different stakeholder roles in executive education versus other modes of study as a main factor in determining key stakeholders. Both categories are consistent with the tensions between multiple and diverse stakeholders we identified earlier, yet both tell us in greater detail about the nature of these tensions.

\section{Should students be key stakeholders?}

First, the majority of interviewees took the ideological position that students should take top position as the key stakeholder. After all, students are the principal consumers of management education and should therefore be the most important stakeholder. Accordingly, interviewees were quick to assert the students should be top of the pile, yet many would cite competing demands that meant this was not always the case. Interviewees grappled with this contradiction in the process of working-through their answers. For example, one respondent articulates the problem as follows: 
"You'd think that in order of priority it should be students and employers at the top. ...but I think that it doesn't always work out that way in practice."

Students are also seen as key stakeholders because of the relationship between business as consumers of skilled graduates and business schools as suppliers of this resource. As such, businesses and employers emerge among the foremost stakeholders as a result of their position in the labour market as customers seeking skilled managers. This perception of management education as a supply-chain arrangement reinforces the position of students at the very core of management education. This maintains the view that business schools must serve to develop skilled individuals who provide significant added value to business. Again, our interviews revealed that business schools are subject to competing pressures, not least to function as a legitimate academic department while keeping the customers happy:

"[It] leads to an academic dilemma because if you treat the student as a customer then you are compromising the academic side of the business... ...somehow they have to balance the idea of being an academic institution but also being a business that is selling bodies to companies"

This response summarises the constant tensions existing between teaching and research, with what amounts to a balancing act - an academic dilemma -for business schools to negotiate. Is it still the case that we as business school Deans continue to enact Steven Kerr's (1995) notorious folly of hoping for excellence in teaching while rewarding research activity? Certainly, the evidence from the ground shows that students are not key stakeholders and it appears that the problem described by Kerr persists.

\section{The relative importance of stakeholders in different types of management education.}

A further observation from our data suggests that the relative importance of stakeholders was contingent on the kind of student in question. Students become increasingly important stakeholders, particularly where companies become involved in executive education.

"There is the education of people for a job, which is the role of post-graduate executive education. There I think that the key stakeholders are the companies... ... And then there is educating younger people, and there I think that the key stakeholder is society and the individual."

Indeed, throughout the interviews it was common for respondents to say 'it depends on what kind of student' and the answer above illustrates how divergent or conflicting stakeholder interests might exist in management education. As another interviewee remarked 'it depends what the product is' and that there are both 'business to business' (b2b) and 'business to consumer' (b2c) activities in business schools. Therefore determining the key stakeholder is again contingent on the kind of student or customer involved. Generally executive courses were perceived as a b2b proposition with business schools providing a service to the businesses that employ these graduates.

Undergraduates, postgraduate and doctoral studies represent a b2c arrangement where key stakeholders are the students themselves and increasingly are subject to broader concerns such as their contribution to society. Clearly students are an extremely important stakeholder, both from an employer and a customer perspective. To assess the relative influence of stakeholders, interviewees 
were asked which stakeholders have had the greatest influence on management education over the last 20 years and to rank order the influence of these stakeholders.

\section{Which stakeholders have had the greatest influence in management education?}

The ranking of influential stakeholders by interviewees presents an interesting contrast to the view point that identified students as the key stakeholder group.

Table 2. Ranking of the most influential stakeholders in management education

\begin{tabular}{|c|c|c|c|c|c|c|c|c|c|c|c|c|c|c|c|c|}
\hline & $\begin{array}{l}\text { Fac } \\
\text { ult } \\
y\end{array}$ & $\begin{array}{l}\text { Busi } \\
\text { nes } \\
\mathrm{s}\end{array}$ & $\begin{array}{l}\text { Stu } \\
\text { den } \\
\text { ts }\end{array}$ & $\begin{array}{l}\text { Aud } \\
\text { itor } \\
\mathrm{s}\end{array}$ & $\begin{array}{l}\text { Gover } \\
\text { nmen } \\
\mathrm{t}\end{array}$ & $\begin{array}{l}\text { No } \\
\text { On } \\
\mathrm{e}\end{array}$ & $\begin{array}{l}\text { Ran } \\
\text { king } \\
\mathrm{s}\end{array}$ & $\begin{array}{l}\text { Busines } \\
\text { S } \\
\text { Schools }\end{array}$ & $\begin{array}{l}\text { Accre } \\
\text { ditor } \\
\mathrm{s}\end{array}$ & $\begin{array}{l}M \\
\text { edi } \\
a\end{array}$ & $\begin{array}{l}\text { Deans/ } \\
\text { Leader } \\
\mathrm{s}\end{array}$ & $\begin{array}{l}\text { Recr } \\
\text { uiter } \\
\mathrm{S}\end{array}$ & $\begin{array}{l}\text { Alu } \\
\mathrm{mn} \\
\mathrm{i}\end{array}$ & $\begin{array}{l}\text { CEO } \\
\mathrm{s}\end{array}$ & $\begin{array}{l}\text { Public } \\
\text { Institu } \\
\text { tions }\end{array}$ & $\begin{array}{l}\text { Euro } \\
\text { pea } \\
\mathrm{n} \\
\text { Scho } \\
\text { ols }\end{array}$ \\
\hline 1st & $\begin{array}{l}43 \\
\% \\
\end{array}$ & $26 \%$ & $14 \%$ & $3 \%$ & $3 \%$ & $3 \%$ & $3 \%$ & $3 \%$ & $3 \%$ & $0 \%$ & $0 \%$ & $0 \%$ & $0 \%$ & $0 \%$ & $0 \%$ & $0 \%$ \\
\hline 2nd & $6 \%$ & $3 \%$ & $3 \%$ & $0 \%$ & $0 \%$ & $0 \%$ & $6 \%$ & $6 \%$ & $0 \%$ & $6 \%$ & $3 \%$ & $3 \%$ & $3 \%$ & $3 \%$ & $3 \%$ & $3 \%$ \\
\hline $\begin{array}{l}\text { 1st } \\
\text { or } \\
\text { 2nd }\end{array}$ & $\begin{array}{l}49 \\
\%\end{array}$ & $29 \%$ & $17 \%$ & $3 \%$ & $3 \%$ & $3 \%$ & $9 \%$ & $9 \%$ & $3 \%$ & $6 \%$ & $3 \%$ & $3 \%$ & $3 \%$ & $3 \%$ & $3 \%$ & $3 \%$ \\
\hline $\begin{array}{l}\text { Top } \\
3\end{array}$ & $\begin{array}{l}49 \\
\%\end{array}$ & $\begin{array}{l}31 \\
\%\end{array}$ & $20 \%$ & $3 \%$ & $3 \%$ & $3 \%$ & $9 \%$ & $9 \%$ & $3 \%$ & $6 \%$ & $3 \%$ & $3 \%$ & $3 \%$ & $3 \%$ & $3 \%$ & $3 \%$ \\
\hline
\end{tabular}

Faculty, business and students emerge as the three most influential stakeholders. With faculty clearly dominant in terms of their influence over management education and yet students deemed to be a key stakeholder, it is inviting to envisage the Gravy Training scenario outlined by Crainer and Dearlove where the relevance of student training comes second to the pursuits of faculty in their ivory towers. If faculty drive the agenda in management education, the simple rankings shown in table 2 give us a helpful yardstick to gauge the relative perceived influence of stakeholders. The detailed responses of our interviewees reveal two different spheres of stakeholder influence in management education: a supply-driven model and demand-driven model of management education over the last 20 years.

The first is a supply-driven perspective where the preferences, terms and conditions of employment and institutional factors mean that faculty call the shots and determine what is taught to students and the areas of research are pursued. Our data contains examples of faculty's influence in the running and direction of business schools, as one interviewee commented:

"Faculty are at the front lines of management education, and in many institutions there's a tradition of family governance and they wield a fair amount of decision making power in some ways because of things like tenure. I think that they've been most influential."

Additionally, interviewees spoke of the way that faculty have shaped and continue to influence teaching in management education. For example:

"[faculty] have historically defined what is taught, and when subjects need to change, and how they need to change. They are the dynamic drivers of change."

With a high level of control over the governance and also of what gets taught in business schools it is possible to see why faculty are perceived as the most influential stakeholders. We regard this as a form of supply-driven management education. 
What also emerged from the data is an indication that both business and students are also perceived as playing a highly influential role in management education. It is this that forms a demand-driven perception of management education. This was especially evident in executive and post-experience courses, possibly because stakeholder interests are much more closely aligned where each student is a de facto representative of business as both an employee and agent of business. Therefore, within a demand-driven form, the sphere of influence is shifted from within academe and is led by consumer demand from student and business stakeholders. Under this scenario the mechanisms of influence for students are that they pay fees - as one respondent commented "extortionate fees". This means that they are positioned to influence how and where courses are delivered and also express demand for specific course content (e.g. finance, management accounting and consultancy skills). Similarly, businesses are seen to be in an influential position either because, like students, they are paying for management education for their staff or prospective staff. It is therefore likely that businesses, following the trials of the global financial crisis and their relative importance in funding higher education, will increasingly influence the agenda and swing the balance of power from the state and academic constituencies. Another mechanism that allows businesses to have a role in driving the classroom agenda is in terms of the kinds of skills and expertise expected from business school graduates. As the ultimate 'consumer', businesses have influence by demanding employable graduates and the skills they should have (e.g. CSR, ethics, sustainability, negotiation and decision making or knowledge management). In a climate of economic recession and a general trend of state austerity, reducing or freezing funding for higher education, the bargaining power of fee-paying students and businesses is strengthened. We should expect the relative influence of students and businesses to increase as they push for value-for-money from management education and pay the bills for business schools.

The rich interview data and our own experiences reveal that much has changed in management education in the 14 years since Crainer and Dearlove's (1999) wake-up call: globalisation, advances in information technology, a continued growth in student numbers, the prominence and expansion of accreditation bodies as well as an increasing focus on performance in rankings are all driving changes in the relationships and influence of stakeholders. It is somewhat surprising that media and professional organisations have not featured highly as influential stakeholders. Both rankings and auditors were seen as influential stakeholder groups by a small number of respondents, yet this is far less than faculty, students and business. The comparatively low perceived influence of rankings and auditors tells only part of the story; there is a link between these stakeholders and the supply- and demand-driven models of management education discussed earlier. On the one hand, rankings have continued to follow the customer, for example, providing information on average earnings and the number of alumni in employment. This reinforces the shift of influence over courses and education toward students or, at least, away from faculty. On the other hand, the concerns of auditors such as EQUIS and AACSB can be seen as more closely aligned with a supply-driven model with their concerns anchored to academic quality. However, many deans and university administrators view rankings as an increasingly important signal of reputation of management education. The tyranny of rankings, as Rakesh Khurana has consistently argued, has a dysfunctional relationship with management education by focussing attention on things like the increase in earnings of graduates or school image rather than either academic concerns or the need for problem solving by businesses. 


\section{Which Individuals have had the Greatest Influence?}

It isn't only businesses, faculty and students that have influenced management education over the last 20 years. We asked interviewees to consider which individuals have been most influential, becoming opinion leaders in the field. From the 36 respondents who answered this question, a population of 56 opinion leaders was produced. Two individuals emerge as definitive opinion leaders, both Henry Mintzberg and Peter Drucker were mentioned most frequently by interviewees. In total, this question provided a list of 47 influential individuals and the top five most frequently nominated influential individuals are shown in table 3 below:

Table 3: Opinion Leaders in management education

\begin{tabular}{|l|r|l|l|}
\hline Leaders & Mentions & Role/Position & $\begin{array}{l}\text { Dean/Head of } \\
\text { School (Yes (Y), No } \\
\text { (N) }\end{array}$ \\
\hline Peter Drucker & $\mathbf{1 3}$ & Guru & $\mathrm{N}$ \\
\hline Henry Mintzberg & $\mathbf{1 3}$ & Guru/Academic & $\mathrm{N}$ \\
\hline CK Prahalad & $\mathbf{6}$ & Academic & $\mathrm{N}$ \\
\hline Michael Porter & $\mathbf{6}$ & Academic & $\mathrm{N}$ \\
\hline & & Academic/ & Y \\
Peter Lorange & $\mathbf{5}$ & Entrepreneur & \\
\hline George Bain & $\mathbf{4}$ & Academic & Y \\
\hline & & Philosophy of & N \\
Charles Handy & $\mathbf{3}$ & ME & \\
\hline Sumantra Ghoshal & $\mathbf{3}$ & Academic & $\mathrm{N}$ \\
\hline Herbert Simon & $\mathbf{3}$ & Academic & $\mathrm{N}$ \\
\hline Jim March & $\mathbf{3}$ & Academic & $\mathrm{N}$ \\
\hline
\end{tabular}

A distinguishing feature of these individuals is their emphasis on management as a practice and their consequent attraction for aspiring leaders. Indeed, Minzberg, Drucker, Prahalad and Porter have dominated Thinkers50 -a global ranking of management thinkers published by business school critics Crainer and Dearlove- since the rankings began in 2001. Drucker was voted top management thinker in 2001 and 2003; Porter in 2005 and Prahalad in 2007 and 2009 underlining their influence on management thought inside and outside management education. Drucker and Mintzberg both stress management as a practice. For Drucker, management is an integrated practice - an art of balancing managing a business, managing managers and managing worker and work. With management practice in mind, Mintzberg holds a mirror up to management education in his book Managers not MBAs which is scathing of the skills taught in management education, not to mention its damaging effect on the quality of management. The birth of management schools leading to a set of core (and competing) disciplines and analytical approaches means that they are often ill-equipped to deliver integrated management education that resembles the skills that Drucker and Mintzberg identify as essential. What we can conclude from this is that management practice requires a holistic and 
integrated set of skills. However, management education is best structured to deliver teaching in discipline oriented silos leaving students with a distorted view of management and the immense task of integrating their own learning.

Another individual in the top 5, Peter Lorange, has also had a direct impact on management education through his initiatives as dean of IMD, the creation of an innovative learning model, and the establishment of the Lorange Institute of Business in Switzerland. These individuals stand-out because we have not yet worked out how to teach the kind of management they describe. Alongside influential individuals are the schools and organisations that deliver management education, we asked respondents to identify which schools have influenced management education.

\section{Which Business Schools or Organisations have had the Greatest Influence?}

Clearly the top 5 schools in Table 4 are IMD, INSEAD, Harvard, LBS and WBS.

Table 4: Distinctly different providers of management education

\begin{tabular}{|l|r|l|l|}
\hline Institution & Unentions & Country/Region & $\begin{array}{l}\text { University/Indepe } \\
\text { ndent }\end{array}$ \\
\hline IMD & 16 & Europe & Independent \\
\hline INSEAD & 11 & Europe & Independent \\
\hline Harvard & 9 & US/N.America & University \\
\hline WBS & 6 & UK/Europe & University \\
\hline LBS & 6 & UK/Europe & Independent \\
\hline Wharton & 5 & US/N.America & University \\
\hline CEIBS & 5 & China/Asia & Independent \\
\hline Cranfield & 4 & UK/Europe & University \\
\hline Open University & 4 & UK/Europe & University \\
\hline None & 4 & & \\
\hline MIT & 4 & US/N.America & University \\
\hline Ashridge & 4 & UK/Europe & Independent \\
\hline Chicago Booth & 3 & US/N.America & University \\
\hline Stanford & 3 & US/N.America & University \\
\hline IESE & 3 & Spain/EU & University \\
\hline Melbourne & 2 & Auz/NZ & University \\
\hline SAID & 2 & UK/Europe & University \\
\hline Dartmouth & 2 & US/N.America & University \\
\hline HKUST & 2 & HK/Asia & University \\
\hline Lancaster & 2 & UK/Europe & University \\
\hline Aalto & 2 & Scandinavia & University \\
\hline Lyon & 2 & France/Europe & Independent \\
\hline Phoenix & 2 & US/N.America & For-profit \\
\hline
\end{tabular}


Insights about IMD, INSEAD and LBS can be gleaned from a recently completed extensive research study (Fernando Fragueiro and Howard Thomas (2011) of the leadership processes in five leading schools: IAE, IMD, INSEAD, LBS and WBS. In the case of IMD (founded 1992/3), INSEAD (founded 1960's) and LBS (founded 1965/66), they examined their internationalising processes in the period of 1990-2004 when these schools transformed from being very strong European schools into excellent, internationally competitive business schools consistently ranked in the top 10-15 of the Financial Times Ranking of Global MBA Programmes. The role of strong Deans, who had the time and courage to implement their visioning and positioning strategies, is evident in the actions of Deans such as Bain in LBS, Borges, de Meyer and Hawawini at INSEAD and Lorange of IMD. Bain faced the challenge of strategic transformation of LBS from a well-known UK school to an international school. He used his strong reputation as a change agent to set a clear strategic change agenda. Borges promoted and strategized the growth of INSEAD as a leading research school and a business school for the world with an overseas campus in Singapore. Lorange shaped IMD's strategy of simplicity with four elements: 'Real Life, real learning', "The global meeting place", "All learning is lifelong learning", and "A minimalist organisational approach".

In this internationalising process each of these schools built up strong reputational and stakeholder capital which led to a very significant level of recognition by other business schools, business leaders, media and professional organisations. Similarly over 100 years HBS has reinforced its strong pioneering reputation and image as a leading business school. It is regarded very highly internationally for its pedagogical innovations including case studies and many textbooks, the influence of the Harvard Business Review and Harvard Business School Press books and the continuing high quality of HBS faculty. They have also reinforced these advantages through consistently stable leadership and a financial endowment that enables them to maintain investments in faculty and innovative management education.

It is no surprise, therefore, to see Harvard, INSEAD, IMD and LBS identified as strong influencers in management education. It should be noted that they are all essentially private universities and in the case of IMD, INSEAD, and LBS 'stand-alone' business schools. WBS, (founded 1967) on the other hand, is an example of a publicly funded, university-based business school which managed to grow innovatively (for example, with the construction of an extremely well-regarded blended distance learning MBA programme) and gained a strong reputation in the context of an entrepreneurial university through the strong initial leadership of Bain and more recently Thomas.

\section{Which Issues do Key Stakeholders Stress?}

Despite a number of significant changes to the context of higher education, no one interviewed suggested that there have been any 'game-changing' innovations within management education. Among respondents there is a sense that far-reaching and high paced change in the macroenvironment drives some of the most important challenges for management education and yet the sector has only responded with incremental change. The key issues identified include information technology, new or emerging subject areas in management education, globalisation, the role of faculty and the influence of competition and performance measures.

\section{Information Technology}


The most commonly cited innovation in management education is the influence of information technology, especially its role in delivering distance and e-learning. However, precisely what impact IT-driven innovation has had on management education is a contested issue. There is no doubt about the pace and change in IT and its influence over higher education in the last 20 years. One respondent captures the changes in IT as follows:

"Well there is obviously the whole area that has to do with technology. It changes the way we live, and interact, and communicate, in the broader sense, so it also has an effect on how people learn"

While there was consensus that much has changed in terms of the capabilities and kinds of technology available, the assessment of how it has changed management education indicates incremental change. The evidence from our interviews suggests that the role of technology has involved more cautious developments through incremental innovation.

"...we fine-tuned our use of technology in the classroom and our understanding and appreciation of it is much better, but do I see anyone who's been totally revolutionary with technology and pedagogy? - I don't think so"

Another area of IT-driven innovation in higher education occurs in the content and delivery of management courses. Bringing teaching and assessment online opens-up great potential for the kind of content that can be distributed across almost the whole world and to a far greater audience than ever before. The growth of distance learning courses (worldwide) is seen as intertwined with innovation in technology as well as innovations in scalable forms of teaching and assessment for management students. Alongside a cautious approach to new technology, interviewees report that there have been relatively minor developments in curricula.

\section{Subject areas in Management Education}

There have been relatively minor developments in management education, indeed, no radical innovation or innovative new paradigm has emerged according to respondents. This suggests that curricula have remained fairly stable.

"There's been the kind of incremental improvements that have allowed us to understand the nature of management itself. So there have been some disparate improvements. But I don't think that they're paradigm shifting. Nor has there been a radical change in curriculum."

Management education maintains its core disciplines and has incorporated some new, faddish topics. However, these often occur within the established disciplinary silos that exist in many schools.

\footnotetext{
"Innovation in subject areas: e.g. entrepreneurship has come through strongly and recently as well as CSR. Some of those I see as faddish, although not entrepreneurship.

Developments have occurred in subject areas such as finance, but I don't necessarily see those as innovation."
}

More recently, there is a sense that deans would like to see more multi-disciplinary, integrated programmes, but are yet to energise a concerted drive towards this ambitious goal. 


\section{Globalisation}

As indicated earlier, globalisation and its influence has been stressed by many authors and the latest AACSB (2011) report. The sense is that adjustments have been made, but there is still considerable growth and challenges that arise from having more students coming from a far wider set of countries than ever before. At the same time, the international diversity of faculty is increasing. Indeed teaching with a global outlook is essential. So much so, internationalisation is incorporated into various high-profile rankings, for example The Financial Times Global MBA rankings include 18\% (20\% including languages) weighting to measures of internationalisation. However, a number of respondents noted that the responses to globalisation have not been uniform throughout the sector, one interviewee summarised the situation as follows:

\footnotetext{
"Business schools, especially in Europe, have been quite good at adjusting to globalisation. I think that this is a very important innovation from being very much European-centric. As for USA schools, they still have a long way to go. Asian schools are already developing a lot. This is an important achievement, because you look at other higher education institutions and you don't see any other type of institution that has been so successful in terms of adjusting."
}

Globalisation presents new challenges, some of which business schools have already started to address and others that will continue to shape the landscape of management education. A fundamental feature of being on the global stage is that competition for the best students, faculty and research is intensified.

\section{The role of faculty}

The role of faculty is thrown into question, particularly in light of new technology and globalisation. There is growing consensus that combination of who, where, what and how we teach is shifting away from so called talk and chalk and towards different combinations of traditional teaching, online and interactive media. An example of this was given by a respondent:

"I always think of the kid in China taking a programme done by an English-speaking faculty member, the fact that it's supported by technology, that they can rewind it and review it, they have a much better chance of getting it than the old way, where we take really good notes and try to internalize those and then the class has gone"

Respondents question whether the role of faculty needs to change, especially where there is a perceived shift away from a supply-driven model of management education. An interviewee portrayed this as a movement away from a model where faculty are the curricula to one where business schools are able to realise scale economies by plugging them into the curriculum to create specialists. This certainly resonates with a demand-driven model of management education.

\section{Competition and performance}

Alongside the pressures from a global theatre for management education, our interviews also signal changes in the competitive dynamics of management education. This takes the form of increasingly strong for-profit organisations including the Apollo Group, Kaplan and corporate universities. The rise in for-profit providers in the market provides both opportunities and threats to incumbents. 
Threats were perceived in the process of breaking-down state-owned monopolies with (typically university-based) schools becoming exposed to market forces through the entry of for-profit providers coupled with a reduction in the level of funding made available by the state. However, a focus on performance has also presented opportunities:

"People talk a lot about competition from the for-profit sector, but they talk less about how business schools have become better at profit seeking. I think that there has been a fair amount of innovation in their ability to seek profits, despite their not-for-profit purpose"

The ability of business schools to generate substantial revenues is a great opportunity and the idea that schools have become better at profit-seeking can be overshadowed by debates surrounding academic legitimacy within universities and their relevance to the management community. Of course, by improving their capabilities as profit-seekers, business schools have become subject to more intense competitive pressures. A constant reminder of competition in the sector emerges from an acute focus on rankings:

"I think that we have to offer state of the art facilities, especially if want to compete for executive education and that sort of thing...... we are concerned now about rankings and league placements and it maybe goes hand in hand with having a smart building and state of the art technology."

These findings reveal that much has changed in the 14 years since Crainer and Dearlove's wake-up call to management education: IT, the subject areas in management, globalisation, the role of faculty and increased competitive pressures present a more complex scenario for business schools to cope with. In addition to these factors, a continued growth in student numbers, a rise in the prominence and scale of accreditation and professional bodies such as AACSB and EQUIS are all driving changes in the relationships and relative influence of stakeholders. However, despite these changes, some of their key criticisms of management education remain which leads us to ask what lessons have not been learned.

\section{Which lessons have not been learned?}

There are several areas where stakeholders believe there are blind spots in management education. These blind spots link closely with two key areas. The first has an interface with the debate surrounding the tensions between rigour and relevance in the management discipline. Crucially, management education cannot meet stakeholder expectations if it is torn between becoming a legitimate academic subject, establishing management as a 'true' profession and providing relevant training while conducting research that addresses real life managerial problems. The second concerns the inertia that exists in established structures and reward systems in management education and the institutional capacity to deal with the pace of change in businesses and organisations. Put simply, what are the major problems within management education and what are the barriers to change that will address these problems?

When discussing the problem of lessons not learned, respondents expressed concern that the activities of teaching, research and problem solving are not meeting the needs of students and businesses. While there was consensus that there is a problem within management education, there 
was limited agreement on precisely where the problem lies. Interviewees provided a range of responses as to where blind spots exist:

"We seem to downgrade the importance of practice-based education and action-based learning in the journey of managers"

It is reasonable to assume that a central concern of management education is to produce better managers and yet a perennial problem is the fact that it does not equip students with practical skills in being managers:

"... We've lost sight of the teaching of skills... ...I think that the role and purpose of business schools is to develop the next generation of business leaders. They need to be equipped with knowledge, certainly, but they also need to be equipped with the 'how to' experience. And we haven't kept pace with that. We've become too research focussed"

Indeed, the shortcomings of providing largely theory-driven management education are also captured by Mintzberg's adage 'managers not MBAs'. Critics of management education have argued that the values and culture instilled in MBAs - by management education- have been instrumental in causing problems such as the current financial crisis:

"We constantly crash into the fact that rational management aimed at profit maximization can often end in tears. We seem constantly surprised that another recession has come around or that some other schmuck has created a mega-scandal"

Yet this situation seems completely counter-intuitive given that the most influential individuals for stakeholders in management education, Drucker and Mintzberg, argue for a far greater understanding of the practice of management as opposed to the alleged narrow, short-term approach adopted by our students. Despite this, management education is structured around disciplinary silos, which offers no or limited integration between management concepts for students. Institutions are structured to deliver teaching in silos that have grown up from the various disciplines that contributed to the formation of business schools:

"...if you just teach finance, for example, you also need to teach the linkages that it isn't finance for finance's sake. Students need to understand what this actually means out in the real world: it isn't just equations, and just investing in stocks and shares, or doing NPV calculations"

This means that there is a serious blind spot in being able to deliver integrated management education, let alone practical management skills.

Overall, the evidence implies that a lack of focus on practice, teaching in silos with no integration, a focus on rational managerial behaviour and academic research all reduce the effectiveness of management education in teaching the 'Art of Managing'. Consequently, there are blind spots in the interface between research and teaching, the quality of teaching as well as the content of management curricula. All of which would help management education to develop better managers and business leaders. 


\section{Can we change management education?}

Given the sometimes conflicting viewpoints of stakeholders and the many issues and lessons not learned that they identify, it is appropriate to ask whether change is possible in ME and its models. Our evidence indicates a common refreshing concern about revitalising curricula and encouraging diversity in teaching and learning approaches. In addition, there is a felt need to understand, through the lessons of history, how business schools got it wrong during the global financial crisis and to stimulate rankings/accreditation agencies to focus more deeply on the schools' educational distinctiveness and programmes rather than a value proposition stressing growth in graduate salaries and reputation.

However, it is evident that business schools occupy a difficult position in attempting to straddle the conflicting goals of academic legitimacy and identity and management practice where, arguably the needs of neither are met! Crainer and Dearlove caricature this predicament with business schools portrayed as schizophrenic organisations that must demonstrate their capacity as 'bona fide' academic institutions, improve knowledge to provide solutions to management problems and at the same time perform as businesses.

Alternative models have nevertheless been suggested for strengthening the perceived legitimacy of business schools in the eyes of management practitioners and other stakeholders. These include stakeholder models such as the 50/20 Initiative, schools in the professional model and schools oriented towards a liberal arts/humanities or knowledge based focus.

But, the key question is whether business schools will exhibit a willingness to change and adopt a new approach to ME? One problem that is the central to answering this question is the quality of leadership by Deans with respect to faculty and staff in business schools. The main issue is the "management of autonomy". How should Deans mediate a decision-making process and serve as a bridge between the interests of external stakeholders and faculty? Collegiality, in terms of critical debate and open communication by faculty and persuasion should dominate bureaucratic control if strategic change is to be successfully implemented by Deans in business schools. Mintzberg confirms that covert forms of strategic leadership are preferred. A metaphor for such a leader might be the conductor of an orchestra. Translation into the business school environment implies little direct supervision from Deans but with "protection and support" that creates legitimacy and reputation for the business school.

The second associated problem is often about the deficit of strategic leadership in many business schools. Deans have been variously described as 'jugglers', 'dictators', 'doves of peace' and 'dragons'. Their roles are seen as multi-faceted, stressful and often characterised as similar to middle managers squeezed between university presidents and demanding faculty members. Further Deans face short tenures (the median tenure of a business school Dean is 3 to 4 years), ambitious goals and critical challenges as they lead schools through their future evolution. As a consequence, particularly of time pressure, many Deans will probably 'muddle through' and make incremental minor changes to their existing business schools models and scenarios. (This is confirmed by the somewhat 'ostrich like' responses by academics in our sample who focus narrowly on improving the status quo). 
A few who have experience, time and the courage, determination and resilience to follow through their chosen path and strategic direction succeed. Success is personified by leaders such as Bain, Borges and Lorange. They reach the quality level described by Jim Collins as Level 5 leaders who possess 'a paradoxical combination of personal humility and professional will'. These are the great leaders who leave behind lasting legacies.

\section{$\underline{\text { References }}$}

AACSB (2011) The Globalisation of Management Education Bingley, U.K.: Emerald Publishing

Crainer, S. and Dearlove, D. (1999) Gravy Training Oxford: Capstone Books

Collins, J.C. (2001) Good to Great New York: Harper Collins

Fraguiero, F. and Thomas, H (2011) Strategic Leadership In The Business School: Keeping One Step Ahead Cambridge: Cambridge University Press

Ghoshal, S. (2005) 'Bad Management Theories are Destroying Good Management' Academy of Management Learning and Education, 4;1: 75-91

Gordon, R. and Howell, J. (1959) Higher Education For Business New York: Columbia University Press

Grey, C.J. (2005) A Very Short, Fairly Interesting And Relatively Cheap Book About Organisations London: Sage

Hamel, G. and Prahalad, C.K. (1994) Competing For The Future Boston, MA: Harvard Business School Press

Kerr, S. (1995) 'An Academy Classic: On The Folly Of Rewarding A While Hoping For B' Academy of Management Executive, 9(1): 7-14

Khurana, R. (2007) From Higher Aims to Hired Hands: The Social Transformation of American Business Schools and the Unfulfilled Promise of Management as a Profession Princeton, N.J: Princeton University Press

Locke, E.R. and Spender, J.C. (2011) Confronting Managerialism London: ZED Books

Mintzberg, H. (2004) Managers Not MBA's Harlow: Pearson Education

Pfeffer, J. and Fong, C.T. (2002) 'The End of Business Schools? Less Success than Meets the Eye' Academy of Management Learning and Education, 1(1), 79-95

Porter, M.E. (1980) Competitive Strategy New York: Free Press

Thomas, Howard 'What is the European Management School Model?' Global Focus, 6, 2012, pp1821

Thomas, Howard, Thomas, Lynne and Wilson, Alexander (2013) Promises Fulfilled and Unfulfilled in Management Education Bingley U.K.: Emerald Publishing 